\title{
Non-destructive analysis of in situ ammonoid jaws by synchrotron radiation X-ray micro-computed tomography
}

\author{
Yusuke Takeda, Kazushige Tanabe, Takenori Sasaki, \\ Kentaro Uesugi, and Masato Hoshino
}

\begin{abstract}
We introduce high-resolution synchrotron radiation X-ray tomography for nondestructive, three-dimensional reconstruction of the jaw apparatus preserved within the body chamber of the Late Cretaceous phylloceratid ammonoid, Phyllopachyceras ezoensis, for the first time. Analysis of the X-ray images using linear absorption coefficient estimation reveals that the upper jaw consisted mainly of inner and outer lamellae composed of carbonate apatite, which originally might have been a chitin-protein complex, with angulated rims of thick calcareous material. The morphological features indicate that the jaw apparatus of this species is the rhynchaptychus-type. The threedimensional architecture of the jaw apparatus of these specimens is similar to that of other ammonoids, except for the development of a thick calcified deposit in both upper and lower jaws, which can be considered to support the predatory-scavenging feeding habits of the species. The jaw features of this species appear to have been constrained by both phylogenetic and functional morphological factors.
\end{abstract}

Yusuke Takeda. Department of Earth and Planetary Science, The University of Tokyo, 7-3-1 Hongo, Bunkyo-ku, Tokyo, 113-0033, Japan. ytakeda@um.u-tokyo.ac.jp

Kazushige Tanabe. Department of Earth and Planetary Science, The University of Tokyo, 7-3-1 Hongo, Bunkyo-ku, Tokyo, 113-0033, Japan.tanabe@um.u-tokyo.ac.jp

Takenori Sasaki. The University Museum, The University of Tokyo, 7-3-1 Hongo, Bunkyo-ku, Tokyo, 1130033, Japan. sasaki@um.u-tokyo.ac.jp

Kentaro Uesugi. Japan Synchrotron Radiation Research Institute (JASRI), 1-1-1, Kouto, Sayo-cho, Sayogun, Hyogo 679-5198 Japan. ueken@spring8.or.jp

Masato Hoshino. Japan Synchrotron Radiation Research Institute (JASRI), 1-1-1, Kouto, Sayo-cho, Sayogun, Hyogo 679-5198 Japan. hoshino@spring8.or.jp

Keywords: Synchrotron radiation; X-ray computed tomography; Ammonoidea; Cretaceous; jaw apparatus; Phylloceratina

Submission: 2 July 2016 Acceptance: 3 October 2016

Takeda, Yusuke, Tanabe, Kazushige, Sasaki, Takenori, Uesugi, Kentaro, and Hoshino, Masato. 2016. Non-destructive analysis of in situ ammonoid jaws by synchrotron radiation X-ray micro-computed tomography. Palaeontologia Electronica 19.3.46A: 1-13 palaeo-electronica.org/content/2016/1636-analysis-of-ammonoid-jaws 


\section{INTRODUCTION}

Virtually all modern cephalopod mollusks possess a well-developed jaw apparatus (synonymous with beak and mandible and consisting of upper and lower elements) and a radula as primary feeding organs, although the radula is vestigial in the pelagic spirulid Spirula (Kerr, 1931), and is reduced or absent in some deep-sea octopods (Voss, 1988; Nixon, 2015). These structures are housed in a globular-shaped muscular buccal mass, in the proximal portion of the digestive tract, and allow for biting and shearing prey (Tanabe and Fukuda, 1999; Nixon, 2015). Both of the upper and lower jaws are made predominantly of a chitin-protein complex, in association with calcareous deposits along the anterior rostral portion of upper and lower jaws in nautilids (Nautilus and Allonautilus) (Saunders et al., 1978; Hunt and Nixon, 1981; Lowenstam et al., 1984; Gupta et al., 2008).

Fossilized remains of ammonoid jaws and radulae have been reported in marine deposits dating to the Paleozoic and Mesozoic eras (Tanabe et al., 2015). They mostly occur individually, but are rarely preserved in situ within the body chambers (e.g., Lehmann, 1967, 1971, 1979; Doguzhaeva and Mutvei, 1992, 1993; Tanabe and Landman, 2002; Kruta et al., 2010, 2011; Landman et al., 2010; Tanabe et al., 2012, 2013; Klug and Jerjen, 2012). Especially when preserved in calcareous and phosphate concretions, they generally retain their original three-dimensional morphology, although their primarily organic composition is replaced by phosphate minerals during diagenesis (Kanie, 1982; Tanabe and Fukuda, 1983; Tanabe et al., 2012; Gupta et al., 2008). Even in such cases, complete extraction of fossilized jaws and radula is technically difficult, as they are embedded in consolidated sedimentary matrices within the body chambers.

To compensate for these technical difficulties, non-destructive techniques, such as X-ray computer tomographic (CT) scans and synchrotron Xray analyses, have been utilized to reconstruct the overall morphology and structure of fossilized jaws and radulae (Kruta et al., 2011, 2013, 2014; Tanabe et al., 2013; see also Sutton et al., 2014, for a recent review on non-destructive techniques in paleontology).

In this study, we attempted to reconstruct the three-dimensional structure and determine the composition of the jaw apparatus that is preserved in situ within the body chamber of a Late Cretaceous phylloceratid ammonoid. The jaw apparatus analyzed herein was previously studied by Tanabe et al. (2013) by means of an industrial X-ray CT scanning machine. For this study, synchrotron radiation X-ray tomographic microscopy was used to obtain better morphological and compositional information. This method emits high flux density monochromatic X-ray beams and allows for the analysis of a small internal structure of specimens with higher spatial resolution quantitatively comparing to laboratory based X-ray micro-CT (e.g., Hagadorn et al., 2006; Donoghue et al., 2006; Chaimanee et al., 2003; Friis et al., 2007; Kruta et al., 2011, 2013, 2014; Han et al., 2016). On the basis of X-ray absorption calculation of the obtained tomographic images, the constituent materials of the fossilized jaw lamellae can be estimated and their original compositions discussed. Then the three-dimensional architecture of the jaw can be compared with other previously known ammonoid and nautilid jaws, and their phylogenetic and functional morphological significance discussed.

\section{MATERIAL AND METHODS}

\section{Material}

A specimen of Phyllopachyceras ezoensis (Yokoyama, 1890) (Phylloceratidae, Phylloceratina), UMUT MM 27831, with upper and lower jaws preserved in situ within the body chamber (Figure 1) was collected from a float calcareous concretion in the Nakakinenbetsu River, Obira area, northwest Hokkaido, Japan. It was possibly derived from the mid-Cretaceous (Turonian) deposits (Tanabe and Landman, 2002; Tanabe et al., 2013). The lower jaw is positioned within the posterior portion of the incomplete body chamber and appears to have retained its original orientation (Figure 1). Though a structure similar to the upper jaw exists in the body chamber, it is invisible to the naked eye (Tanabe et al., 2013). The specimen is housed in the University Museum, the University of Tokyo (UMUT).

\section{Methods}

High-resolution X-ray tomography was performed at SPring-8, a synchrotron radiation facility in Hyogo, Japan. The specimen was placed in the experimental hutch 3 of BL20B2 (Goto et al., 2001), and was scanned by means of propagationbased X-ray phase contrast tomography (Paganin et al., 2002) with a spatial resolution of $26 \mu \mathrm{m} /$ pixel at an energy of $100 \mathrm{keV}$. The distance from the sample to X-ray image detector was $5 \mathrm{~m}$. The Xray transmission images were captured with a sCMOS-based visible light conversion type X-ray 

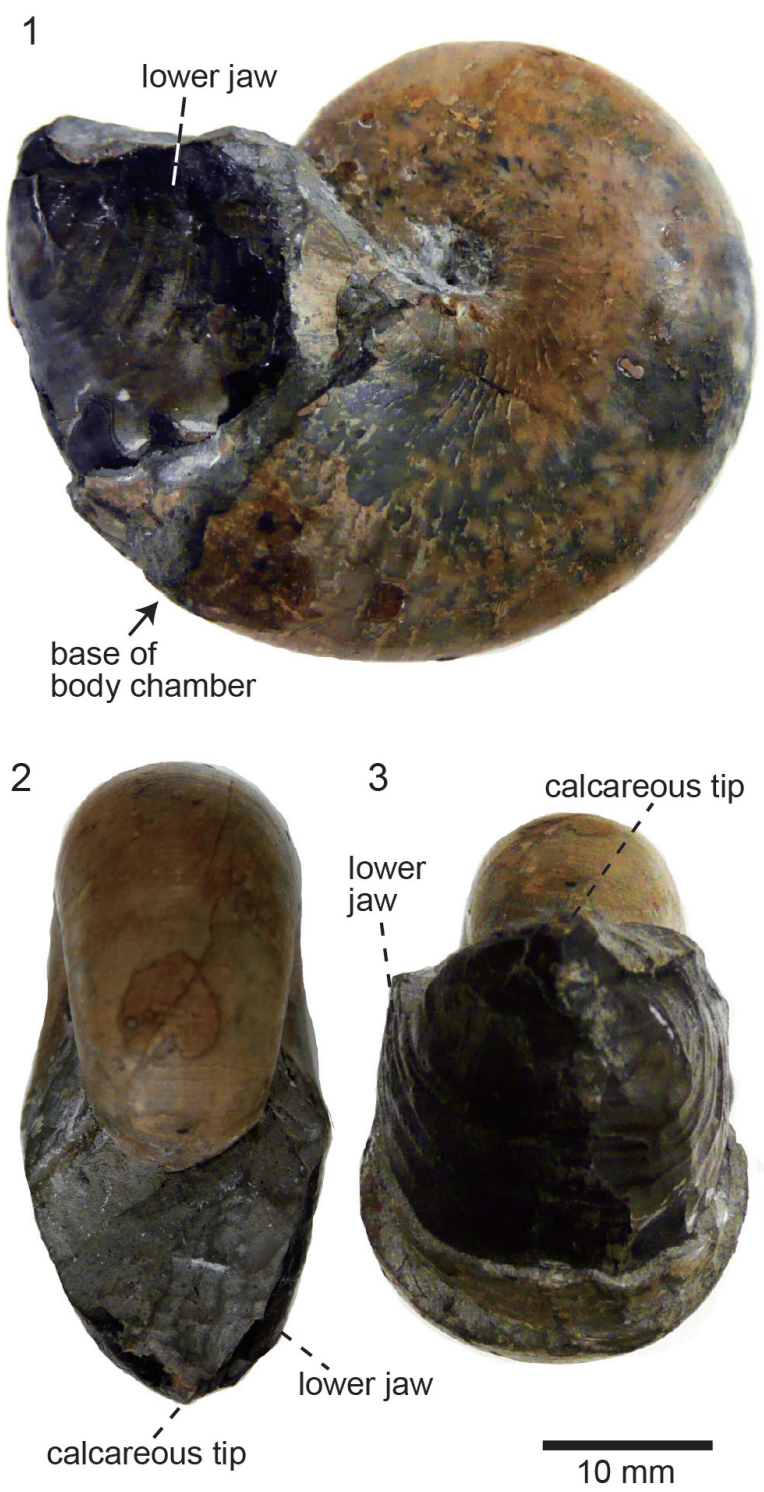

FIGURE 1. Left lateral (1), dorsal (2) and ventral (3) views of Phyllopachyceras ezoensis with preserved upper and lower jaws in situ within the body chamber. UMUT MM 27831 (modified from Tanabe et al., 2013).

image detector (Uesugi et al., 2011, 2012). Because the height of the specimen was large relative to the X-ray beam and it was not possible to scan the entire specimen at once, the specimen was scanned in nine sections from the top to the bottom, each with a vertical and horizontal image size of $4.0 \mathrm{~mm}$ and $53.3 \mathrm{~mm}$, respectively. In each scan, a total of 900 projections with an exposure time of 2 seconds per projection were obtained while rotating the specimen through 180 degrees. The images were then reconstructed into 16 bit greyscale tomographic images using the convolution back projection method after the phase retrieval (Paganin's method).

The luminance of the tomographic images was analyzed using a freeware Fiji (Schindelin et al., 2012) to estimate the composition of the specimen based on the X-ray linear absorption coefficient. The segmentation and three-dimensional reconstruction of the tomographic images were performed using Amira 3.5.5 (Visage Imaging, Inc.). The segmentation was performed using the Magic Wand and Brush tools built into the software. The morphological terms for ammonoid upper and lower jaws are those found in Tanabe et al. (2015, figure 10.4).

\section{RESULTS}

\section{Tomographic Images}

The median section of the specimen was reconstructed from the X-ray tomographic images (Figure 2). Based on these images, orthogonal cross sections were also reconstructed (Figure 3). Based on the contrast luminance present in the images, the internal state of the specimen could be distinguished and several structural elements recognized (Figure 2.2).

The body chamber is filled with muddy sediments, as visible to the naked eye. Individual camerae in the phragmocone are mostly filled with aggregated, possibly carbonate material, though several late-formed camerae are partially vacant (Figure 2.2). Carbonate crystals within the camerae appear to have precipitated from seawater during fossilization, which is a common manner of preservation for ammonoid fossils (e.g., Wani and Gupta, 2015). The septa and outer shell wall are composed of a darker colored material with a lower luminance in comparison to the aggregated filling within the camerae. The siphuncle is partially observable in the X-ray CT images as a tube with a lighter colored (i.e., a higher luminance value) wall. The anterior and posterior portions of the lower jaw, which are not visible to the naked eye, are composed of lighter and darker materials with different luminance values (Figure 2.3). Similarly, on the posterior side of the body chamber, the upper jaw is distinguishable from the surrounding sediment matrix (Figure 2.4) and appears v-shaped in the cross-sections (Figure 3 ). It is composed of lighter and darker-colored materials with the lighter-colored material appearing to be covered with the darker one. 

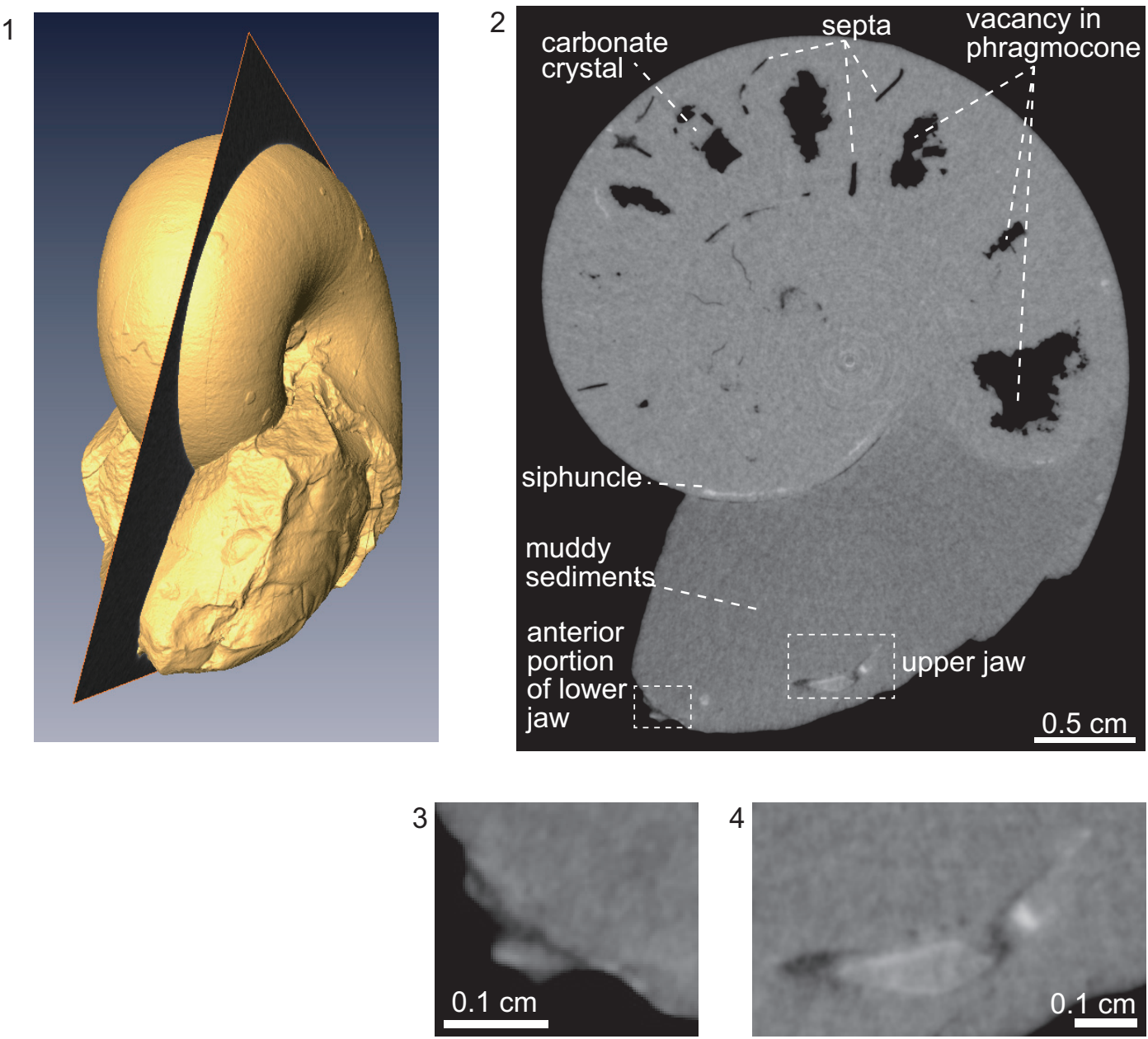

FIGURE 2. Reconstructed tomographic images of the specimen (1) and its internal structure in median section (2). The lower and upper jaws are enlarged in (3) and (4), respectively.

\section{Estimation of Constituent Materials of the Fossilized Jaw Lamellae}

The nature of the light and dark-colored regions of the X-ray tomographic images was evaluated on the basis of the linear absorption coefficient (LAC). In this synchrotron radiation experiment, the luminance value of the tomographic images represents the LAC value of the specimen. Because the LAC for a given material can be calculated on the basis of its constituent elements, density, and X-ray energy (Chantler et al., 2005), the material shown on the tomographic images was identified by comparing the luminance value with the calculated LAC of the hypothesized material composition. Figure 4 and Table 1 summarize the LAC for each part of the specimen determined by the luminance value. The linear relationship between LAC and luminance value relies upon the assumption of the presence of air outside of the specimen and the presence of aggregated carbonates (assumed to be calcite) in the phragmocone. Based on this analysis, chitin was ruled out as the material make-up of both the dark and light-colored materials of the upper jaw. Rather, the LAC for the light-colored material of the upper jaw is quite similar to the calculated LAC for fluorapatite $\left(\mathrm{Ca}_{5}\left[\mathrm{PO}_{4}\right]_{3} \mathrm{~F}\right)$. Previous authors reported that black-colored jaw lamellae of Late Cretaceous ammonoids from Hokkaido are made of carbonate apatite, as determined by X-ray diffraction (Kanie, 1982; Tanabe and Fukuda, 1983; Tanabe et al., 2012). The rhychaptychus-type jaw apparatuses of Lytoceratina and Phylloceratina and the intermediate-type ones of Desmoceratoidea from the Upper Cretaceous deposits of Hokkaido are composed mainly of carbonate apatite, with a calcitic and/or aragonitic covering (Kanie, 1982; Tanabe et al., 2012, 2013). Judging from these lines of evidence, the light-colored jaw material observed in X-ray images of the $P$. ezoensis is 

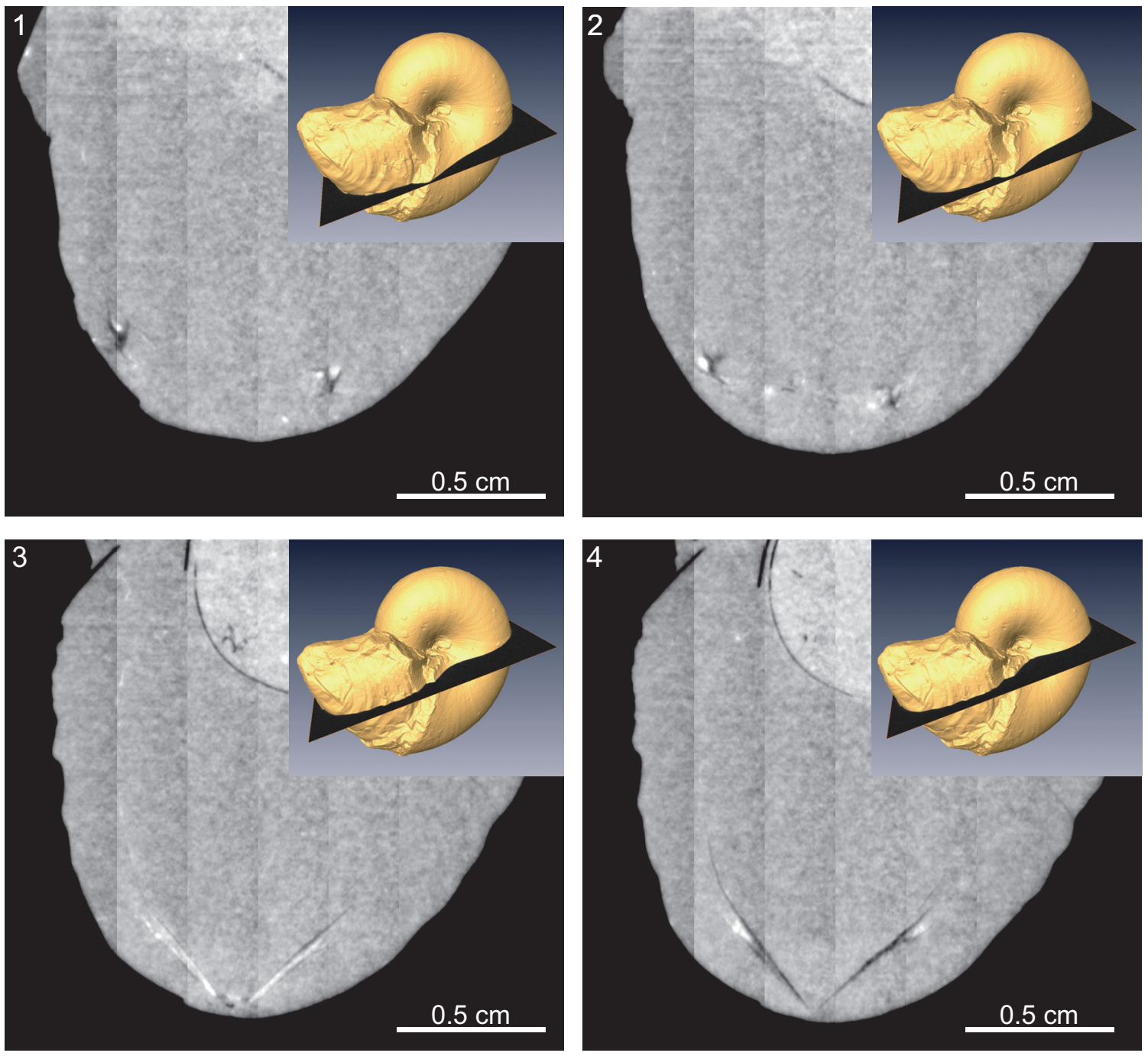

FIGURE 3. Serial cross-sections of the body chamber portion of the specimen cut from the venter (1) to the dorsum (4), in which sectioned images of the upper jaw are shown. Note that the vertical stripes are due to the separated scanning.

presumed to be fluorapatite, whereas the darkly colored material corresponds to the calcareous covering. It can be interpret that the light-colored jaw material was originally primarily composed of a chitin-protein complex as in modern cephalopod jaws, which during diagenesis changed into carbonate apatite. This material is described as "chitinous" material hereafter. Although the LAC of the dark-colored region differs from carbonates, this might be the result of the dissolution of carbonates during diagenesis. It is notable that the luminance values of most septa are similar to those of the carbonate covering of the jaws, suggesting that the primarily aragonitic shell portions of the specimen have been entirely changed into calcite during diagenesis. This diagenetic replacement is also con- firmed by the naked eye, because the outer shell portion loses iridescence and is altered into brownish material.

\section{Segmentation and Three-Dimensional Reconstruction}

Segmented tomographic images of upper and lower jaw portions were compiled and their threedimensional shapes were created (Figure 5). The segmentation of the lower jaw is incomplete, as three-dimensional reconstruction was successful only anteriorly and posteriorly (Figure 6.1). In the anterior portion, calcareous material covers the inner rim of the outer "chitinous" lamella, forming the calcified rostrum (Figure 6.1, 6.2). The calcareous material would have covered the entire outer 


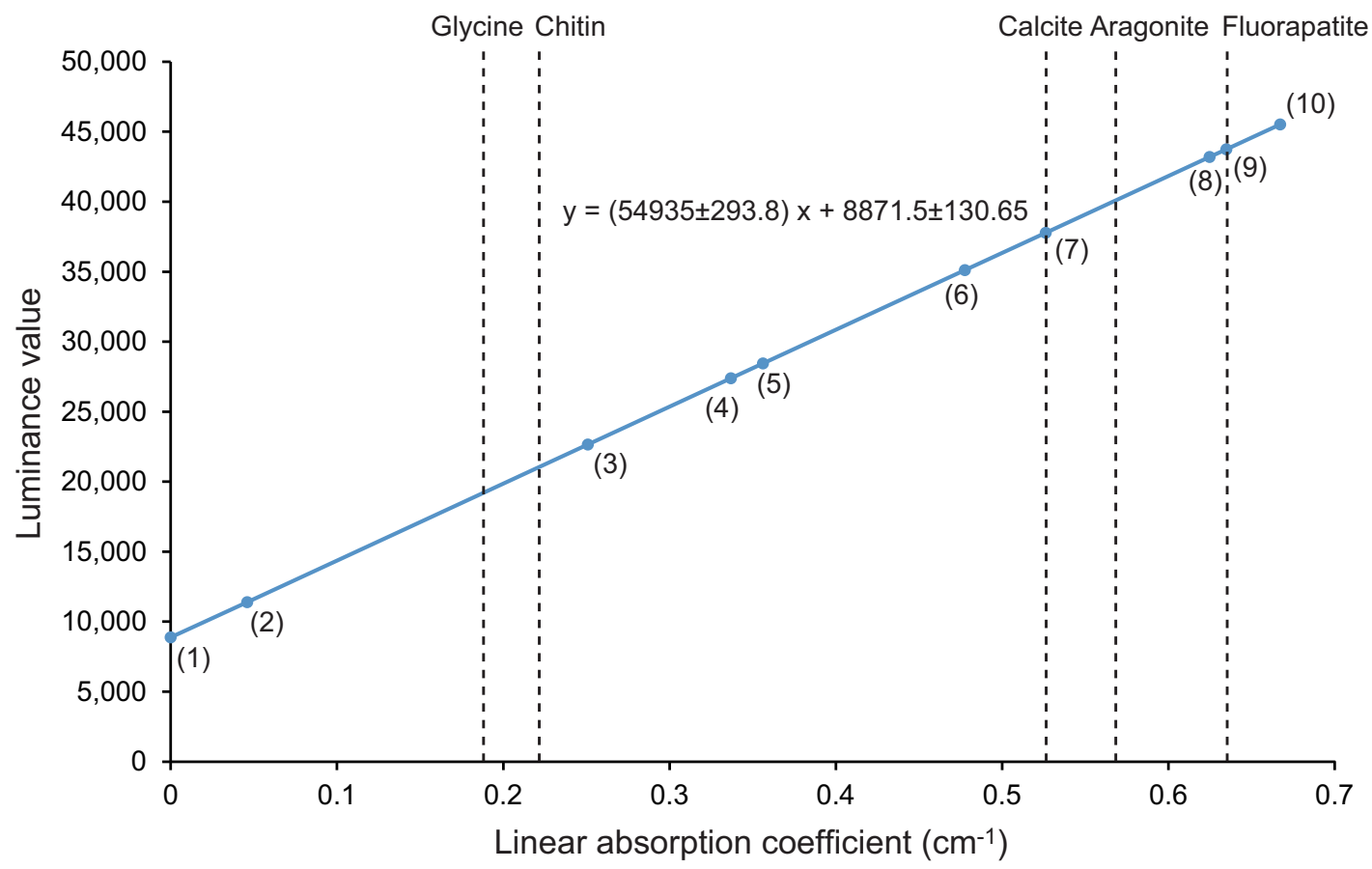

FIGURE 4. Linear absorption coefficient (LAC) of the internal portions of the specimen estimated by their mean luminance values in the tomographic images. The numbers (1)-(10) correspond to the materials in Table 1 . The dashed lines indicate the known values for the materials (Chantler et al., 2005) that could be expected to be observed in the specimen. Note that glycine is the most dominant amino acid in jaws of Octopus vulgaris (Hunt and Nixon, 1981). The relationship between LAC values and luminance values is based on the assumption that the LAC values for the surrounding air are zero and that the crystals precipitated in the phragmocone are calcite.

surface of the rostrum at one point (Figure 6.3), but it might have been removed during the preparation of the specimen. The inner lamella of the lower jaw is not distinct in this specimen. In the posterior portion of the jaw, the outer surface of the "chitinous" lamella was covered with a calcareous layer (Figure $6.1,6.2$ ).
The upper jaw has an angular, wing-like shape (Figure 7.1-4). The light-colored "chitinous" material composes the outer and inner lamellae, which are joined in the anterior portion. The overall shape of the outer lamella is not curved, but angular and shaped like an arrowhead. The anteriormost portion of the outer lamella is sharply pointed, forming the rostral tip (Figure 7.5). The calcareous

TABLE 1. Linear absorption coefficient (LAC) in the tomographic images of the Phyllopachyceras ezoensis. The numbers (1)-(10) correspond to plots in Figure 4.

\begin{tabular}{lcccc}
\hline & mean & minimum & maximum & standard deviation \\
\hline air surronding the specimen (1) & 0.000 & -0.001 & 0.003 & 0.0015 \\
phragmocone vacancy (2) & 0.046 & 0.027 & 0.068 & 0.0123 \\
septa (3) & 0.251 & 0.199 & 0.343 & 0.0467 \\
lower jaw (dark-colored part) (4) & 0.337 & 0.317 & 0.351 & 0.0103 \\
upper jaw (dark-colored part) (5) & 0.356 & 0.333 & 0.384 & 0.0149 \\
sediments in body chamber (6) & 0.478 & 0.473 & 0.483 & 0.0040 \\
carbonate crystal in phragmocone (7) & 0.526 & 0.516 & 0.538 & 0.0067 \\
siphuncle (8) & 0.625 & 0.610 & 0.645 & 0.0136 \\
upper jaw (light-colored part) (9) & 0.635 & 0.581 & 0.708 & 0.0525 \\
lower jaw (light-colored part) (10) & 0.667 & 0.633 & 0.706 & 0.0262 \\
\hline
\end{tabular}


1

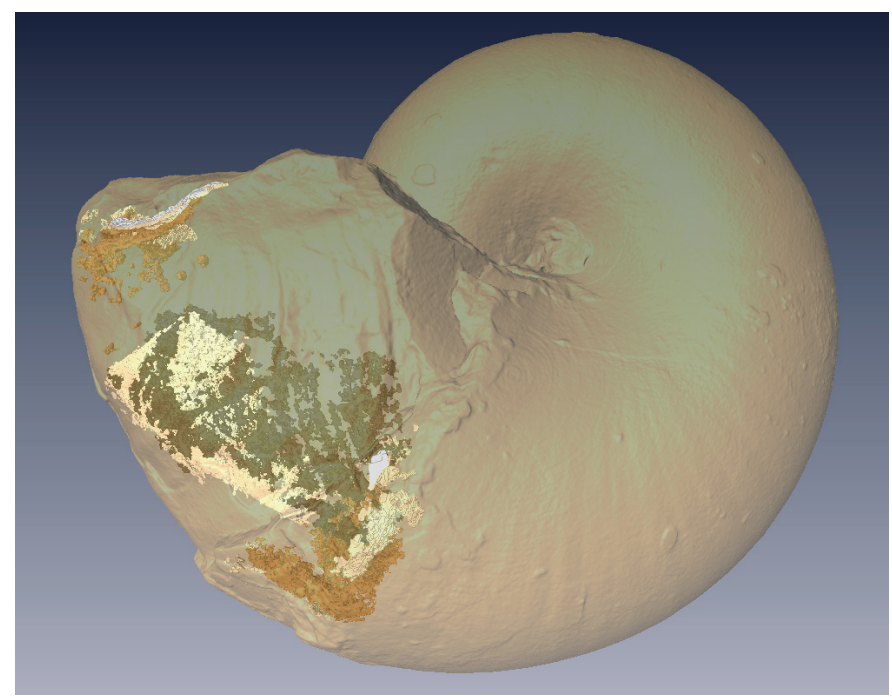

2

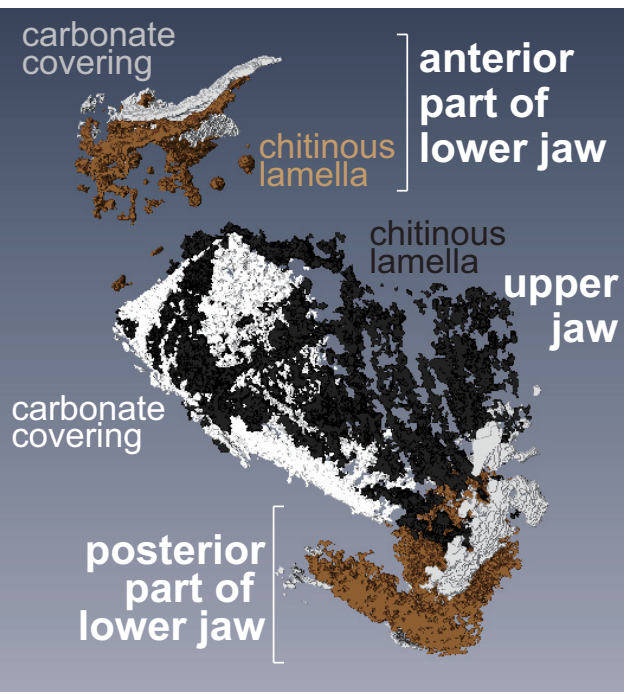

FIGURE 5. Three-dimensional reconstruction of the upper and lower jaws preserved in the body chamber of the specimen. The reconstructed parts are inside the specimen (1). The jaws are preserved close to each other (2).

layer covers the entire outer lamella, but is thickly deposited along its angular rims, as if it forms a frame that encloses the "chitinous" outer lamella. The "chitinous" inner lamella is longer than the outer lamella and extends posteriorly, forming paired lateral walls (Figure 7.5). Similar to the inner lamella, the upper rims of these walls are covered by a thick calcareous material. The transverse section of the inner lamella just behind the rostrum reveals that the lateral faces of the inner lamella are folded inwardly at their enter (Figure 7.6), and the inner surface of the inner lamella is thinly covered with a calcareous layer.

\section{DISCUSSION}

Our analysis by synchrotron radiation X-ray tomographic microscopy revealed the detailed morphology of the upper and lower jaws of the examined $P$. ezoensis. They are relatively large compared to its conch (although the greater portion of the body chamber was lost after fossil preparation), as briefly described by Tanabe and Landman (2002). Our experiment confirms the observation by Tanabe et al. (2013) that the upper jaw consists of paired larger inner lamellae (lateral walls) and a short outer lamella (hood), all of which are united in the anterior portion, forming a thick and sharply pointed rostral tip (Figure 7). X-ray tomographic image analysis based on the linear absorption coefficient (LAC) revealed that the lamellae of both the upper and lower jaws are composed of carbon- ate apatite and carbonate material, which are represented by higher and lower-LAC in the tomographic images (Figures 5-7), respectively. The former is covered by the latter (Figures 6, 7). These morphological features indicate that the jaw apparatus of the studied species can be classified as the rhynchaptychus-type, as previously described by Tanabe et al. (2013). However, our observations suggest that the high and low-LAC materials represent a "chitinous" substance and calcareous deposit, respectively, as opposed to the view of Tanabe et al. (2013) that the darker outer lamella (hood) is wholly covered by paired lateral walls that consisting of a dense and light material.

In the suborder Phylloceratina, in situ occurrences of upper and lower jaws is only known in the Late Cretaceous Hypophylloceras subramosum (Tanabe et al., 2013) and Phyllopachyceras ezoensis (Tanabe et al., 2013; this study). In addition, Hauff (1953, pl. 75, figure F) described an anaptychus, a wholly "chitinous" lower jaw preserved in situ within the body chamber of a Phylloceras heterophyllum from the Toarcian (Lower Jurassic) Posidonia Shale of Holzmaden, southern Germany. The Phylloceras specimen is, however, flattened, and its aragonitic shell wall and septa were dissolved during diagenesis; hence exact morphological comparison with the lower jaw of the Phyllopachyceras described herein is difficult.

Besides these in situ jaws, Bachmayer (1963) reported lamellaptychi, a type of aptychus-type lower jaw consisting of an inner "chitinous" lamella 
1

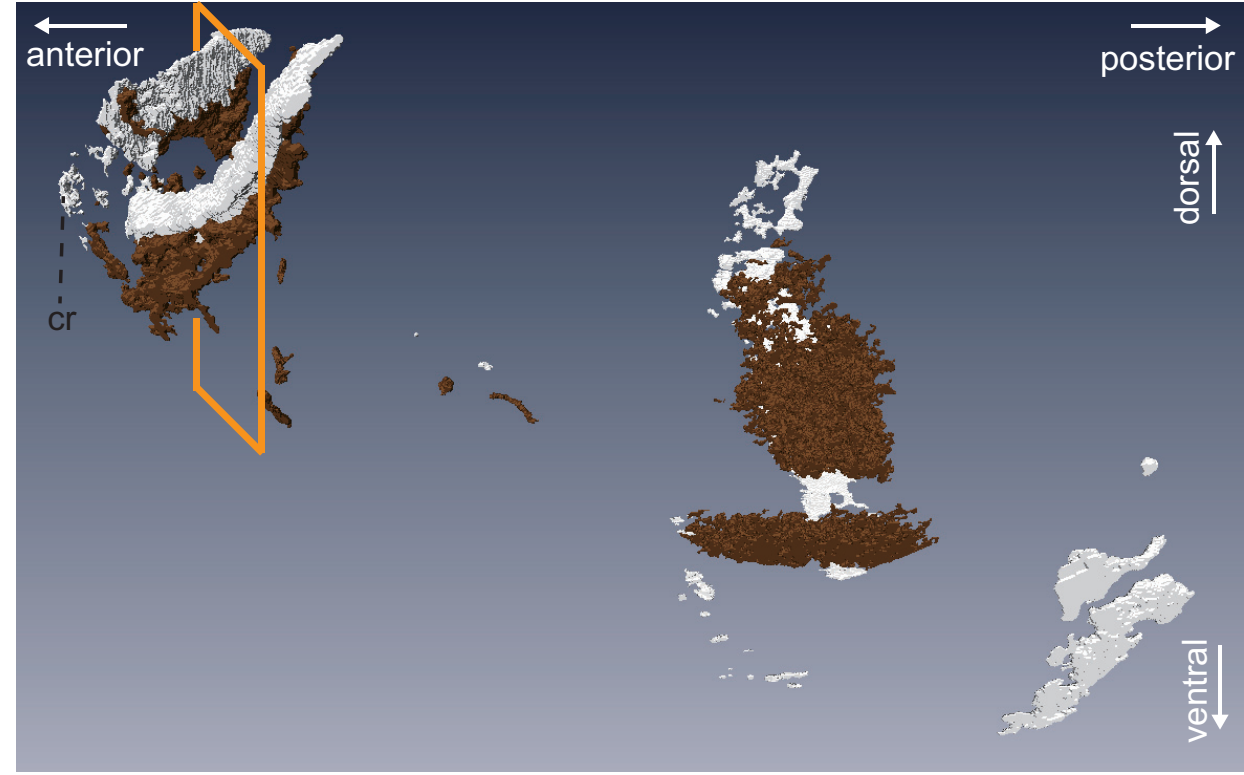

2

3
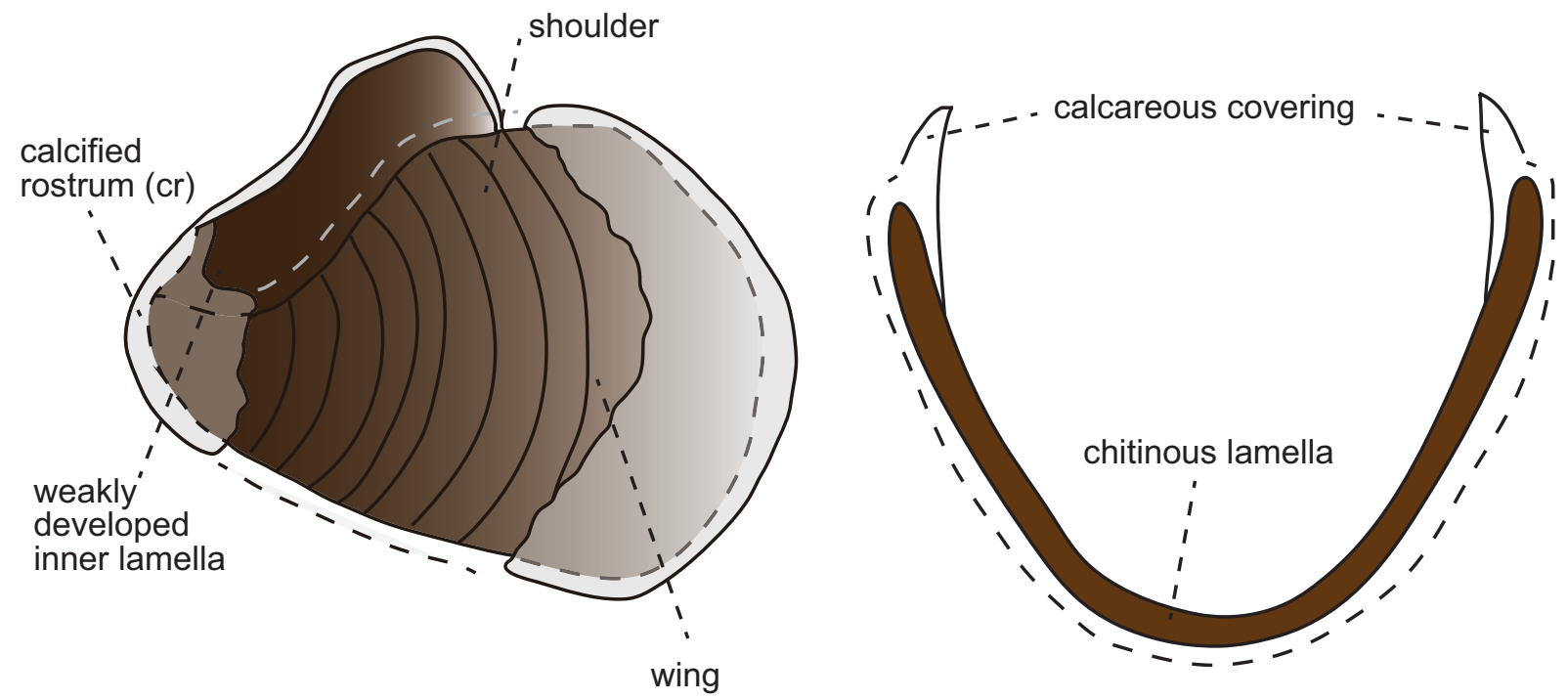

FIGURE 6. Result of segmentation of the lower jaw of the specimen, from lateral view which is restricted to its anterior and posterior portion (1). Three-dimensional reconstruction (2) suggests a wide distribution of calcareous material. The outer calcareous layer on the outer "chitinous" layer is partly taken off in (2). The transverse section of the area indicated as a square in (1) shows that the calcareous covering of the lower jaw also covers the internal surface of the "chitinous" lamella (3). The abbreviation is indicated in (2).

and outer bi-valved calcitic plates, in the body chambers of the Late Jurassic Calliphylloceras from Austria. More recently, Mitta and Schweigert (2016) described another kind of lower jaw consisting of a "chitinous" outer lamella with a distinct median depression forming paired wings in the body chamber of a Calliphylloceras conch from the Middle Jurassic of the northern Caucasus. However, the presence of two kinds of lower jaw in the same ammonoid genus is unlikely (Tanabe et al.,
2015), and the lamellaptychus-lower jaw-upper jaw conch association has been found in the Jurassic Haploceratoidea of the suborder Ammonitina. For these reasons, it can be concluded that the lower jaws reported by Bachmayer (1963) have an allochthonous origin and might have been trapped within the empty body chambers of Calliphylloceras during the biostratinomic process, as suggested by Engeser and Keupp (2002) and Vašíček (2010). We also doubt the autochthonous nature 
1

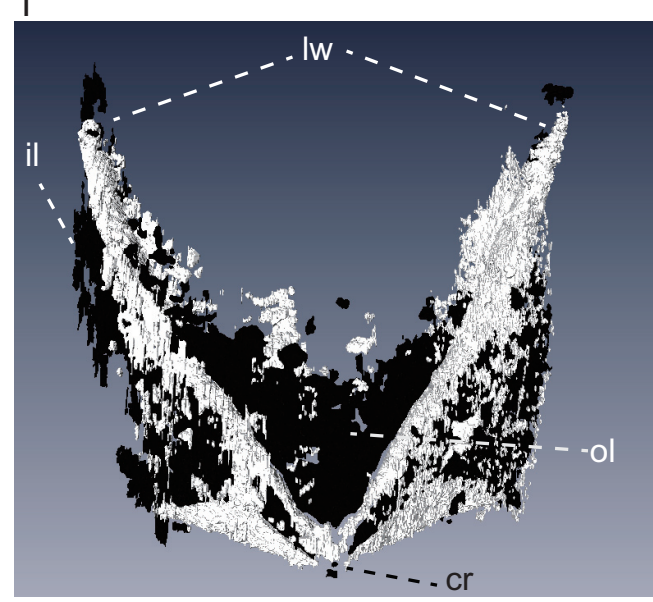

2

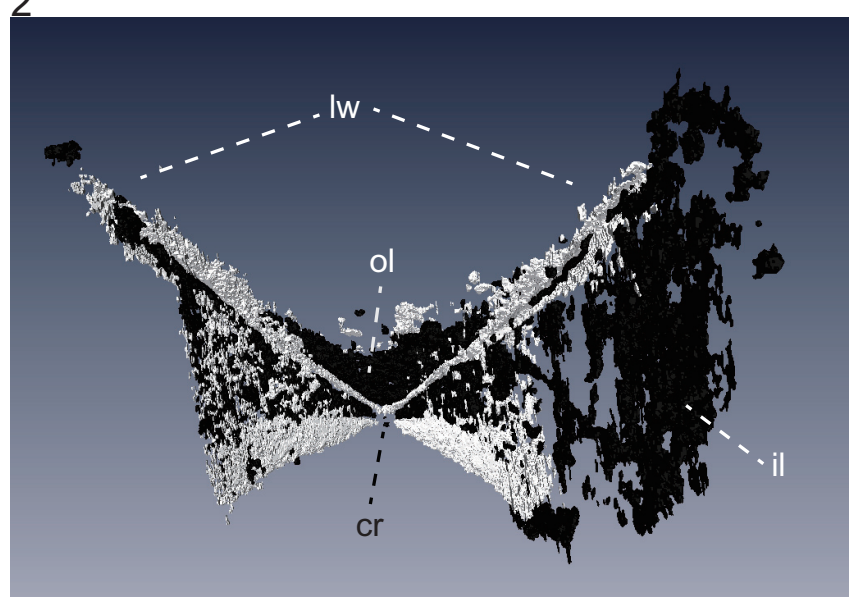

3

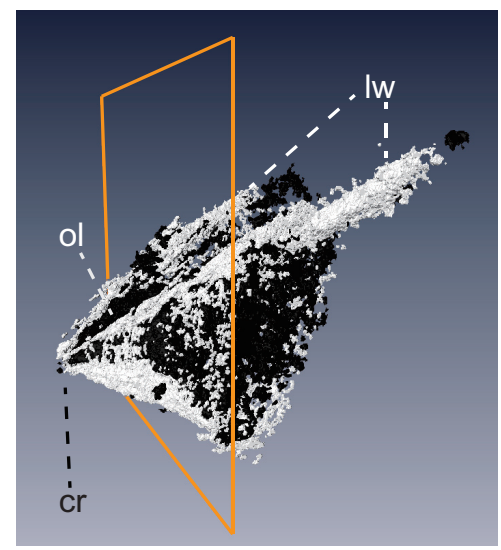

4

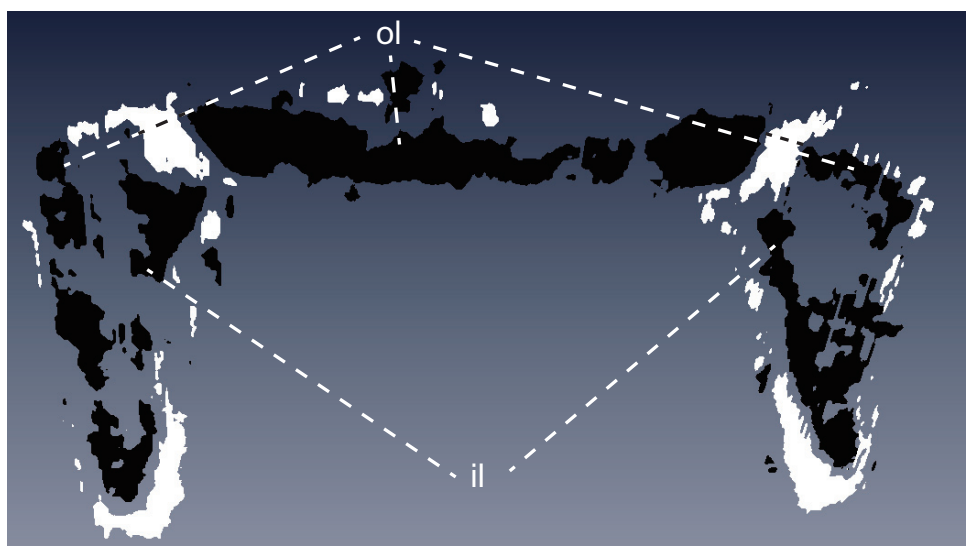

5

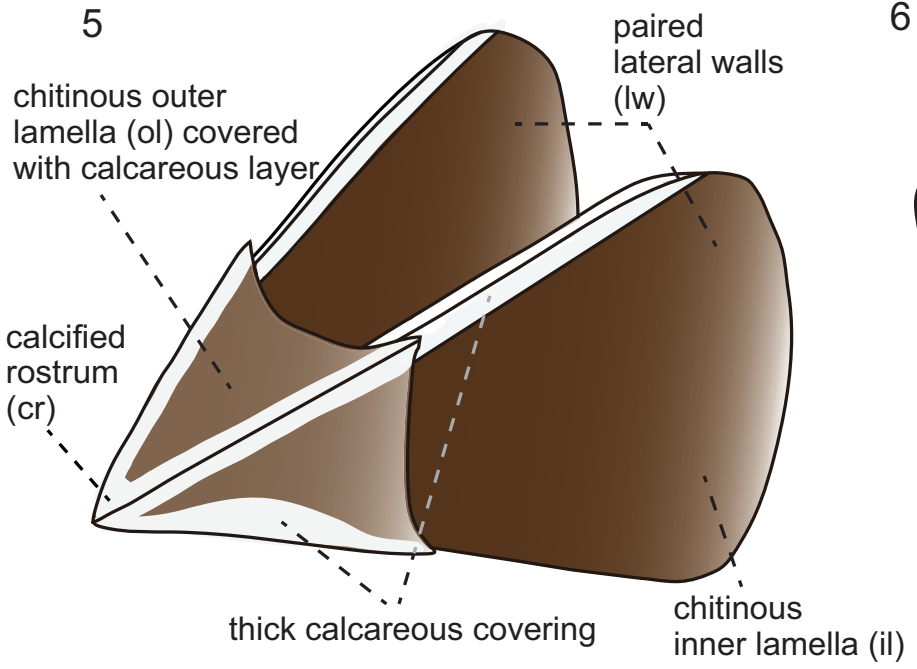

6
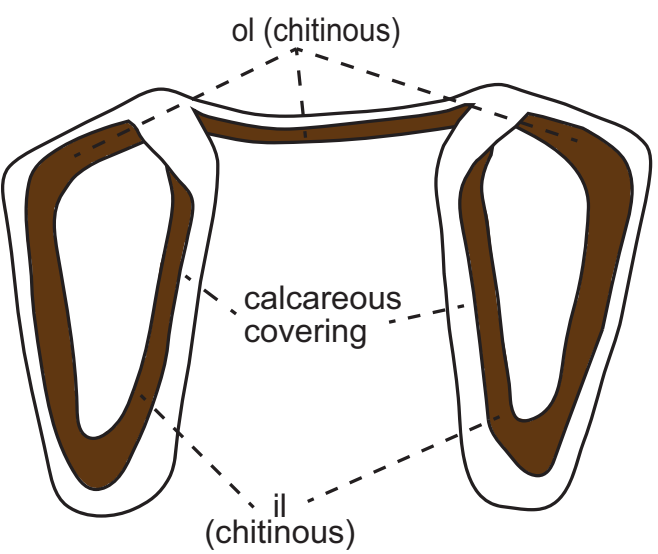

(chitinous)

FIGURE 7. Result of segmentation of the upper jaw of the specimen, from frontal (1), rear (2), left-lateral (3) views and the transverse section of the area (4) indicated as a square in (3). The three-dimensional reconstruction (5) shows areal distributions of the "chitinous" lamellae and the calcareous covering. The reconstruction of the transverse section (6), which corresponds to (4), shows the architecture of the outer lamella. The abbreviations are indicated in (5). 
for the lower jaw reported in the body chamber of another Calliphylloceras specimen described by Mitta and Schweigert (2016). Additional Calliphylloceras specimen with preserving upper and lower jaws inside the body chamber is needed to confirm the adequacy of their interpretation.

The gross morphology of the lower jaw of $P$. ezoensis resembles that of $H$. subramosum (Tanabe et al., 2013). The upper jaws of these species are also similar, with the exception of two major differences; namely, 1) the outer lamella of $P$. ezoensis has much closer contact with the paired inner lamellae than that of $H$. subramosum, and 2) the paired inner lamellae of $P$. ezoensis are covered by a calcareous layer, unlike those of $H$. subramosum.

In the modern Nautilus, the chitinous lamellae of the upper and lower jaw are covered with a thin aragonitic layer upon which a thick calcitic deposit overlays inward at the rostrum (Lowenstam et al., 1984). Consequently, the calcareous covering is the thickest at the anterior portion of the rostrum. The distinction between aragonite and calcite is impossible to determine in the examined specimen of $P$. ezoensis, because the original aragonitic shell mineralogy has not been preserved.

Arrowhead- and scallop-shaped calcareous coverings of organisms are called rhyncholites and conchorhynchs, respectively (Teichert et al., 1964). They have been found from the Late Paleozoic and younger marine deposits, and some of them from the Jurassic and Cretaceous are interpreted to be the calcified deposits of the upper and lower jaws of either lytoceratid or phylloceratid ammonoids (see review by Tanabe et al., 2015). The overall morphology of the calcareous covering of the lower jaw of the examined $P$. ezoensis could be comparable to other known conchorhynchs (e.g., Teichert et al., 1964; Saunders et al., 1978) and conchorhynch-like structures of Lytoceratina (Tanabe et al., 1980; Kanie, 1982) and Phylloceratina (Tanabe and Landman, 2002; Tanabe et al., 2013). However, that of the upper jaw of $P$. ezoensis is quite different from other known rhyncholites. Although the absence of a mid-dorsal projection from the anterior calcareous portions in the examined specimen is a characteristic of Rhynchotuethis, a morphotype of rhyncholites (e.g., Teichert et al., 1964; Teichert and Spinosa, 1971; Riegraf and Luterbacher, 1989; Nemoto and Tanabe, 2008; Riegraf and Moosleitner, 2010), a shaft-like prolongation that extends into the concave interior of the upper jaw, which is the general characteristic of the known rhyncholites (Teichert et al., 1964), is absent in $P$. ezoensis. Such specific feature of the calcareous deposits on $P$. ezoensis upper jaw might be as a result of ecological-functional constraints (as discussed later).

The existence of a calcareous covering is a characteristic feature of the jaw apparatuses of the Cretaceous lytoceratid and phylloceratid ammonoids (Tanabe et al., 2015) and modern and fossil nautilids (Saunders et al., 1978; Klug, 2001). Based on observations of feeding behaviors (e.g., Mikami et al., 1980) and investigations of the stomach contents of modern nautilids (e.g., Saisho and Tanabe, 1985), the calcareous covering has been considered to aid in biting and shearing prey, so it is presumed that it developed for predatory and/or scavenging modes of feeding. The wide distribution of calcareous material on both the upper and lower jaws of $P$. ezoensis might also have served to reinforce the jaws, indicating relatively active feeding habits (scavenging-predatory modes of feeding) as postulated in previous studies (e.g., Tanabe et al., 2013, 2015).

Dagys et al. (1989) reconstructed by means of serial sectioning and compared the overall morphology and lamellar structure of the jaw apparatuses of Middle Triassic ceratitid ammonoids, Early Jurassic ammonoid Hildaites levisoni, and unknown Late Cretaceous ammonoids presumably belonging to either Lytoceratina or Phylloceratina. These three jaw types can be referred to respectively as the normal, aptychus, and rhynchaptychus-types on the basis of the jaw morphotype classification by Tanabe et al. (2015). According to Dagys et al. (1989, figures 2, 4, 5), in both normal and rhynchaptychus-type lower jaws, the inner and outer lamellae are united in the dorsolateral portion of the rostrum and are separated posteriorly. Although the detailed structure is not distinct, this condition appears to be observed in the lower jaw of the $P$. ezoensis examined here (Figure 6.2). In contrast, in the aptychus-type lower jaw of $\mathrm{H}$. levisoni, the outer and inner lamellae are largely united in the anterolateral portion of the rostrum and shoulder (Dagys et al., 1989, figure 4a, c).

As for the upper jaw, in normal-type of Triassic ceratitids, the inner and outer lamellae are united in the dorsolateral portion of the rostrum but are separated at its ventrolateral portion, whereas in aptychus-type of Early Jurassic Hildaites, the outer and inner lamellae are united in the ventrolateral portion of the rostrum (Dagys et al., 1989, figures 1b, 3 ). The transverse section of the upper jaw of the examined $P$. ezoensis shows that the outer lamella is distinctly folded inward at its venter to form the 
inner lamella (Figure 7.6), which has a shape similar to the normal-type upper jaw.

The rhynchaptychus, anaptychus, and aptychus-type jaw apparatuses of Mesozoic Ammonoidea differ significantly in their overall shape, the presence or absence of a calcified element, and surface ornamentation (Tanabe et al., 2015). It remains unclear whether or not the morphological variability of the jaw apparatuses in post-Jurassic Ammonoidea (Tanabe and Landman, 2002; Engeser and Keupp, 2002) was constrained by phylogenetic factors, functional morphologic factors, or both. However, this study and a previous report (Dagys et al., 1989) reveal that they share similar fundamental chitinous lamellar structures of both the upper and lower jaw, suggesting phylogenetic control. Meanwhile, the development of a calcareous jaw element in various Jurassic and Cretaceous ammonoids might have been constrained mainly by ecological-functional morphologic factors, as discussed by Parent et al. (2014) for bivalved calcitic plates of the lower jaw (aptychi in a strict sense), and as discussed by Tanabe et al. $(1980,2013,2015)$ for the thick calcified rostral tips of the rhynchaptychus-type jaw apparatus. The fairly large variation in jaw morphology and the variety of food remains in the crop/stomach and buccal cavities known in Mesozoic ammonoids may reflect diversity in dietary habits, ranging from predatory-scavenging to microphagous (zooplankton-feeding) habits. Future comparative morphological examinations of better-preserved jaw remains and analyses of food remains found in the crop/stomach and buccal cavities by means of synchrotron radiation X-ray tomography could solve these problems.

\section{CONCLUSIONS}

Synchrotron radiation X-ray tomographic analysis with linear absorption coefficient estimation reveals the three-dimensional architecture and compositions of the jaw apparatus of the Late Cretaceous phylloceratid ammonoid, Phyllopachyceras ezoensis. The upper jaw consists mainly of inner and outer lamellae composed of carbonate apatite, which originally might have been a chitinprotein complex, with angulated rims of a thick calcareous material. The lower jaw consists of widely opened outer and highly reduced inner "chitinous" lamellae, whose outer surfaces and anterior inner portions are covered by a calcareous material. These features indicate that the jaw apparatus of the present species can be classified as the rhynchaptychus-type.
The three-dimensional architecture of the jaw apparatus of the examined species is essentially similar to those of other ammonoid jaw types, except for the development a thick calcified deposit on both of the upper and lower jaws. A phylogenetic factor would have influenced the architecture of the "chitinous" lamellae, whereas a functional morphological factor is much more important for the development of the calcareous covering.

\section{ACKNOWLEDGEMENTS}

The synchrotron radiation experiment was performed at the BL20B2 of SPring-8 with the approval of the Japan Synchrotron Radiation Research Institute (JASRI) (Proposal No. 2015A1907 and 2013A1441). This study is supported in part by JSPS KAKENHI Grant Numbers JP16J06269 to Y.T.; JP26400498 to K.T.; JP15K14589 to T.S. We thank two anonymous reviewers for their comments and suggestions to improve the manuscript.

\section{REFERENCES}

Bachmayer, V.F. 1963. Beiträge zur Palaeontologie oberjurassicher Riffe. I. Die Aptychen (Ammonoidea) des Oberjura von Stramberg (ČSR). II. Die Aptychen der KIrntnitzer Serie in Österreich. Annalen des Naturhistorischen Museums in Wien, 66:125-138.

Chaimanee, Y., Jolly, D., Benammi, M., Tafforeau, P., Duzer, D., Moussa, I., and Jaeger, J-J. 2003. A middle Miocene hominoid from Thailand and orangutan origins. Nature, 422:61-65.

Chantler, C.T., Olsen, K., Dragoset, R.A., Chang, J., Kishore, A.R., Kotochigova, S.A., and Zucker, D.S. 2005. X-Ray Form Factor, Attenuation and Scattering Tables (version 2.1). National Institute of Standards and Technology, Gaithersburg, MD. physics.nist.gov/ ffast [accessed on 2016, April 28th]

Dagys, A.S., Lehmann, U., Bandel, K., Tanabe, K., and Weistchatt, W. 1989. The jaw apparati of ectocochleate cephalopods. Paläontologische Zeitschrift, 63:41-53.

Doguzhaeva, L.A. and Mutvei, H. 1992. Radula of the Early Cretaceous ammonite Aconeceras (Mollusca: Cephalopoda). Palaeontographica Abteilung, 223:167-177.

Doguzhaeva, L.A. and Mutvei, H. 1993. Shell ultrastructure, muscle-scars, and buccal apparatus in ammonoids. Geobios Mémoirs Special, 15:111-119.

Donoghue, P.C.J., Bengtson, S., Dong, X-p., Gostling, N.J., Huldtgren, T., Cunningham, J.A., Yin, C., Yue, Z., Peng, F., and Stampanoni, M. 2006. Synchrotron X-ray tomographic microscopy of fossil embryos. Nature, 442:680-683. 
Engeser, T. and Keupp, H. 2002. Phylogeny of aptychipossessing Neoammonoidea (Aptychophora nov., Cephalopoda). Lethaia, 24:79-96.

Friis, E.M., Crane, P.R., Pedersen, K.R., Bengtson, S., Donoghue, P.C.J., Grimm, G.W., and Stampanoni, M. 2007. Phase-contrast X-ray microtomography links Cretaceous seeds with Gnetales and Bennettitales. Nature, 450:549-52.

Goto, S., Takeshita, K., Suzuki, Y., Ohashi, H., Asano, Y., Kimura, H., Matsushita, T., Yagi, N., Isshiki, M., Yamazaki, H., Yoneda, Y., Umetani, K., and Ishikawa, T. 2001. Construction and commissioning of a 215m-long beamline at SPring-8. Nuclear Instruments and Methods in Physics Research, A467-468:682685.

Gupta, N.S., Briggs, D.E.G., Landman, N.H., Tanabe, K., and Summons, R.E. 2008. Molecular structure of organic components in cephalopods: evidence for oxidative cross linking in fossil marine invertebrates. Organic Geochemistry, 39:1405-1414.

Hagadorn, J.W., Xiao, S., Donoghue, P.C.J., Bengston, S., Gostling, N.J., Pawlowska, M., Raff, E.C., Raff, R.A., Turner, F.R., Chongyu, Y., Zhou, C., Yuan, X., McFeely, M.B., Stampanoni, M., and Nealson, K.H. 2006. Cellular and subcellular structure of Neoproterozoic animal embryos. Science, 314:291-294.

Han, J., Kubota, S., Li, G., Ou, Q., Wang, X., Yao, X., Shu, D., Li, Y., Uesugi, K., Hoshino, M., Sasaki, O., Kano, H., Sato, T., and Komiya, T. 2016. Divergent evolution of medusozoan symmetric patterns: Evidence from the microanatomy of Cambrian tetramerous cubozoans from South China. Gondwana Research, 31:150-163.

Hauff, B. 1953. Das Holzmadenbuch. Hohenloheschen Buchhandlung, Öhringen.

Hunt, S. and Nixon, M. 1981. A comparative study of protein composition in the chitin-protein complexes of the beak, pen, sucker disc, radula and oesophageal cuticle of cephalopods. Comparative Biochemistry and Physiology, 68B:535-546.

Kanie, Y. 1982. Cretaceous tetragonitid ammonite jaws: a comparison with modern Nautilus jaws. Transactions and Proceedings of the Palaeontological Society of Japan, New Series, 125:239-258.

Kerr, J.G. 1931. Notes upon the Dana specimen of Spirula and upon certain problems of cephalopod morphology. Dana-Report, 8:1-34.

Klug, C. 2001. Functional morphology and taphonomy of nautiloid beaks from the Middle Triassic of southern Germany. Acta Palaeontologica Polonica, 46:43-68.

Klug, C. and Jerjen, I. 2012. The buccal apparatus with radula of a ceratitic ammonoid from the German Middle Triassic. Geobios, 45:57-65.

Kruta, I., Landman, N.H., Rouget, I., Cecca, F., and Larson, N.L. 2010. The Jaw apparatus of the Late Cretaceous ammonite Didymoceras. Journal of Paleontology, 84:556-560.

Kruta, I., Landman, N., Rouget, I., Cecca, F., and Tafforeau, P. 2011. The role of ammonites in the Meso- zoic marine food web revealed by jaw preservation. Science, 331:70-72.

Kruta, I., Landman, N.H., Rouget, I., Cecca, F., and Tafforeau, P. 2013. The radula of the Late Cretaceous ammonite Rhaeboceras halli. Palaeontology, 56:914.

Kruta, I., Mapes, R., Pradel, A., Tafforeau, P., and Landman, N.H. 2014. New insights into the buccal apparatus of the Goniatitina; paleobiological and phylogenetic implications. Lethaia, 47:38-48.

Landman, N.H., Mapes, R.H., and Cruz, C. 2010. Jaws and soft tissues in ammonoids from the Lower Carboniferous (Upper Mississippian) Bear Gulch Beds, Montana, USA, p. 147-153. In Tanabe, K., Sasaki, T., Shigeta, Y., and Hirano, H. (eds.), CephalopodsPresent and Past, Tokai University Press, Tokyo.

Lehmann, U. 1967. Ammoniten mit Kieferapparat und Radula aus Lias-Geschieben. Paläontologische Zeitschrift, 41:25-31.

Lehmann, U. 1971. Jaws, radula, and crop of Arnioceras. Palaeontology, 14:338-341.

Lehmann, U. 1979. The jaws and radula of the Jurassic ammonite Dactylioceras. Palaeontology, 22:265-271.

Lowenstam, H.A., Traub, W., and Weiner, S. 1984. Nautilus hard parts: a study of the mineral and organic constitutions. Paleobiology, 10:269-279.

Mikami, S., Okutani, T., Hirano, H., Kanie, Y., and Hamada, T. 1980. Behavior in captivity, p. 11-22. In Hamada, T., Obata, I., and Okutani, T. (eds.), NautiIus macromphalus in Captivity. Tokai University Press, Tokyo.

Mitta, V.V. and Schweigert, G. 2016. A new morphotype of lower jaw associated with Calliphylloceras (Cephalopoda: Ammonoidea) from the Middle Jurassic of the Northern Caucasus. Paläontologische Zeitschrift, 90:293-297.

Nemoto, T. and Tanabe, K. 2008. New record of a rhyncholite (cephalopod upper jaw element) from the Maastrichtian of Hokkaido, Japan. Palaeontological Research, 12:303-306.

Nixon, M. 2015. The buccal apparatus of Recent and fossil forms. Treatise Online 69, Part M, Chapter 12. Paleontological Institute, University of Kansas, Lawrence, Kansas, 1-30.

Paganin, D., Mayo, S.C., Gureyev, T.E., Miller, P.R., and Wilkins, S.W. 2002. Simultaneous phase and amplitude extraction from a single defocused image of a homogeneous object. Journal of Microscopy, 206:3340.

Parent, H., Westermann, G.E.G., and Chamberlain, J.A., Jr. 2014. Ammonite aptychi: Functions and role in propulsion. Geobios, 47:45-55.

Riegraf, W. and Luterbacher, H. 1989. Jurassic and Cretaceous rhyncholites (cephalopod jaws) from the North Atlantic Ocean (Deep Sea Drilling Project Leg 1-79) and their European counterparts. Evidence for the uniformity of the Western Tethys. Geologische Rundschau, 78:1141-1163. 
Riegraf, W. and Moosleitner, G. 2010. Barremian rhyncholites (Lower Cretaceous Ammonoidea: calcified upper jaws) from the Serre de Bleyton (Départment Drôme, SE France). Annalen des Naturhistorischen Museums in Wien, Serie A 112:627-658.

Saisho, T. and Tanabe, K. 1985. Notes on the oesophagus and stomach-contents of Nautilus pompilius in Fiji. Kagoshima University, Research Center for the South Pacific, Occasional Papers, 4:62-64.

Saunders, W.B., Spinosa, C., Teichert, C., and Banks, R.C. 1978. The jaw apparatus of Recent Nautilus and its palaeontological implications. Palaeontology, 21:129-141.

Schindelin, J., Arganda-Carreras, I., Frise, E., Kaynig, V., Longair, M., Pietzsch, T., Preibisch, S., Rueden, C., Saalfeld, S., Schmid, B., Tinevez, J.-Y., White, D.J., Hartenstein, V., Eliceiri, K., Tomancak, P., and Cardona, A. 2012. Fiji: an open-source platform for biological-image analysis. Nature Methods, 9:676-682.

Sutton, M.D., Rahman, I.A., and Garwood, R.J. 2014. Techniques for Virtual Palaeontology. Wiley, New York.

Tanabe K, and Fukuda, Y. 1983. Buccal mass structure of the Cretaceous ammonite Gaudryceras. Lethaia, 16:249-256.

Tanabe, K. and Fukuda, Y. 1999. Morphology and function of cephalopod buccal mass, p. 245-262. In Savazzi, E. (ed.), Functional Morphology of the Invertebrate Skeleton. John Wiley \& Sons, London.

Tanabe, K., Fukuda, Y., Kanie, Y., and Lehmann, U. 1980. Rhyncholites and conchorhynchs as calcified jaw elements in some late Cretaceous ammonites. Lethaia, 13:157-168.

Tanabe, K., Kruta, I., and Landman, N.H. 2015. Ammonoid buccal mass and jaw apparatus, p. 429484. In Klug, C., Korn, D., De Baets, K., Kruta, I., and Mapes, R.H. (eds.), Ammonoid Paleobiology: From Anatomy to Ecology. Springer, Dordrecht.

Tanabe, K. and Landman, N.H. 2002. Morphological diversity of the jaws of Cretaceous Ammonoidea. Abhandlungen der Geologischen Bundesanstalt, 57:157-165.
Tanabe. K., Landman, N.H., and Kruta, I. 2012. Microstructure and mineralogy of the outer calcareous layer in the lower jaws of Cretaceous Tetragonitoidea and Desmoceratoidea (Ammonoidea). Lethaia, 45:191-199.

Tanabe, K., Misaki, A., Landman, N.H., and Kato, T. 2013. The jaw apparatuses of Cretaceous Phylloceratina (Ammonoidea). Lethaia, 46:399-408.

Teichert, C., Moore, R.C., and Nodine Zeller, D.E. 1964. Rhyncholites, p. K467-K484. In Moore, R.C. (ed.), Treatise on Invertebrate Paleontology, Part K, MolIusca 3. Geological Society of America and University of Kansas Press, Boudler, Colorado, and Lawrence, Kansas, 1-519.

Teichert, C. and Spinosa, C. 1971. Cretaceous and Tertiary rhyncholites from the western Atlantic Ocean and from Mississippi. University of Kansas, Paleontological Contributions, 58:1-10.

Uesugi, K., Hoshino, M., and Yagi, N. 2011. Comparison of lens- and fiber-coupled CCD detectors for X-ray computed tomography. Journal of Synchrotron Radiation, 18:217-223.

Uesugi, K., Hoshino, M., Takeuchi, A., Suzuki, Y., and Yagi, N. 2012. Development of fast and high throughput tomography using CMOS image detector at SPring-8. Proceedings of SPIE, 8506:85060I

Vašíček, Z. 2010. Aptychi and their significance for taxonomy of Lower Cretaceous ammonites. Journal of National Museum (Prague), Natural History Series, 179 (18):183-188.

Voss, G.L. 1988. Evolution and phylogenetic relationships of deep-sea octopods (Cirrata and Incirrata), p. 253-276. In Clarke, M.R., Trueman, E.R. (eds.), The Mollusca, Paleontology and Neontology of Cephalopods, vol. 12. Academic Press. San Diego.

Yokoyama, M. 1890. Versteinerungen aus der japanischen Kreide. Palaeontographica, 36:159-202.

Wani, R. and Gupta, N.S. 2015. Ammonoid taphonomy, p. 555-598. In Klug, C., Korn, D., De Baets, K., Kruta, I., and Mapes, R.H. (eds.), Ammonoid Paleobiology: From Macroevolution to Paleogeography. Springer, Dordrecht. 